\author{
(online) $=$ ISSN $2285-3642$ \\ ISSN-L = $2285-3642$ \\ Journal of Economic Development, Environment and People \\ Volume 2, Issue 4, 2013 \\ URL: $\underline{\text { http://jedep.spiruharet.ro }}$ \\ e-mail: office jedep@spiruharet.ro
}

\title{
CO2 Embodied in Trade between Poland and Selected Countries
}

\author{
Jan T. Mizgajski \\ Department of Market Conditions Research, Faculty of Commodity Science, Poznan University of \\ Economics, Poland
}

\begin{abstract}
This study is aimed at analyzing the carbon embodied in trade flows between Poland and its major trade partners. Calculations are based on the data from the GTAP database for the year 2004. The study uses an input-output analysis, which allows responsibility to be assigned to individual flows for generating specific amounts of emissions in the economy. It is shown that Polish exports contain significantly more embodied carbon than Polish imports, despite the fact that the value of the imports is higher. Moreover, it is found that among the surveyed countries, only three were net importers of carbon emissions to Poland. Export to Germany is responsible for the most of emissions in Poland. In turn, Poland receives the most emissions from imports from Russia.
\end{abstract}

Keywords: Carbon dioxide, embodied emission, Input-Output analysis

JEL Codes: Q53, Q56, Q58

\section{Introduction}

The growing interest in climate change serves the development of interdisciplinary research combining various areas of interest in this phenomenon. Economic science benefits heavily from this, most often addressing issues concerning the economic impact of climate change and of climate policy. Since the primary goal of climate policy is the reduction of greenhouse gases, the study of the causal relationships between emissions of these gasses and the economy is of interest to economics. Those relationships can be studied under various aspects, one of which is foreign trade. The problem was first approached after the adoption of the United Nations Framework Convention on Climate Change (UN FCCC) in 1992, which aimed at stabilizing anthropogenic greenhouse gas emissions, especially carbon dioxide $\left(\mathrm{CO}_{2}\right)(1992)$. Precursors of the current study have addressed the fact that developed countries, when obliged to reduce their emissions, import many goods and services from developing countries, thereby contributing to the growth of greenhouse gas emissions in those countries (Wyckoff and Roop 1994; Subak 1995; Schaeffer and Andre 1996; Lenzen 1998). This was, as it turned out, a real threat to the effectiveness of global efforts to reduce 


\author{
(online) = ISSN $2285-3642$ \\ ISSN-L = 2285-3642 \\ Journal of Economic Development, Environment and People \\ Volume 2, Issue 4, 2013 \\ URL: $\underline{\text { http://jedep.spiruharet.ro }}$ \\ e-mail: office jedep@spiruharet.ro
}

emissions. It is difficult to treat the reduction of emissions in one country as effective if it entails a growth in imports and an accompanying increase in indirect emissions in the exporting countries. This has been observed in the case of the emissions of the United Kingdom (Helm, Smale et al. 2007). In this way, emission sources are merely moved from one country to another. Trade here acts not only as a factor leading to economic growth through increasing efficiency of resource allocation, but also as a mechanism which allows environmentally burdensome production to move to countries with lower environmental standards(Rhee and Chung 2006). One method of measuring the indirect responsibility for pollution emissions, including greenhouse gas emissions, outside a given country, is to measure the so-called emissions embodied in trade. Emissions embodied in trade include all emissions which were emitted in country $A$ in order to generate trade flows from country A to country B.

One of the important reasons for studying the greenhouse gas emissions embodied in trade is to identify the effect known as carbon leakage. This phenomenon is based on the growth of greenhouse gas emissions in countries with have no emission reduction commitments, thanks to the reductive measures taken by other countries. This issue is often discussed in the literature of climate change economics (Metz, Davidson et al. 2007; Peters and Hertwich 2008; Bernard and Vielle 2009; Kuik and Hofkes 2010). Apart from this, there are also practical reasons for conducting this research. Peters and Hert wich convincingly argue that emissions embodied in trade have a significant impact on participation in and the effectiveness of global climate policies such as the Kyoto Protocol (2008). Furthermore, knowledge about them can be applied in creating national and regional policies for climate change mitigation. This confirms the growing interest in adapting trade policy measures for climate policy purposes. (Neuhof 2007; Zhang 2009; Dissou and Eyland 2011). Besides what has already been indicated, an inventory of emissions induced abroad is useful in determining the indirect responsibility for their formation. This allows us to observe the actual reduction efforts of different countries and groups of states.

In recent years, the number of works on embodied emissions has systematically increased. A review of over 50 paper son this topic from the period 2007-2009 has been written by Wiedmann (2009). Since that time, many new articles have been published. A significant number of them focus on emissions embodied in trade flows. The vast majority of published works concern China, and analyse the influence on worldwide $\mathrm{CO}_{2}$ emissions of exports from that country (Yunfeng and Laike 2010), the influence of individual sectors on the emissions embodied in Chinese exports (Lin and Sun 2010; Su, Huang et al. 2010), and the way in which carbon emissions are embodied in China's trade with Japanand the USA (Dong, Ishikawa et al. 2010; Guo, Zou et al. 2010; Liu, Ishikawa et al. 2010). Among the studies focused on other countries, one can find analyses of $\mathrm{CO}_{2}$ emissions implicated in Austria's trade(Gavrilova, Jonas et al. 2010; Munoz and Steininger 2010), as well as publications presenting global emission flows between individual countries and groups of countries (Chen Z. and Chen G.Chen, Chen et al. 2010; Atkinson, Hamilton et al. 2011; Chen and Chen 2011). So far, there is a lack in the literature of a study that would in particluar focus on emissions embodied in trade with Poland. This is the goal of this article.

The study presents the influence that multilateral trade relations have on $\mathrm{CO}_{2}$ emissions in Poland and abroad. To this end, the 20 countries with which Poland has the greatest volume of trade are analysed 


\author{
(online) $=$ ISSN $2285-3642$ \\ ISSN-L = $2285-3642$ \\ Journal of Economic Development, Environment and People \\ Volume 2, Issue 4, 2013 \\ URL: $\underline{\text { http://jedep.spiruharet.ro }}$ \\ e-mail: office jedep@spiruharet.ro
}

here. The basic research questions concern the amount of $\mathrm{CO}_{2}$ emissions in Poland resulting from the export of Polish goods and services to those countries, and the emissions in those countries resulting from the export of their goods and services to Poland. Questions are raised concerning the direct and indirect effects of trade-associated emissions, and about the level of carbon intensity in trade flows between Poland and the analysed countries.

The outline of the work is as follows: section 2 describes the applied methodology and data sources, section 3 presents and discusses the results of the analysis of the emissions embodied in trade between Poland and its major trade partners, and the last section contains the conclusions of the study.

\title{
2. Methods
}

This study uses the methodology for calculating emissions embodied in bilateral trade (EEBT) (Peters 2008). The EEBT is calculated based on data from international trade statistics in monetary units. Because the method does not distinguish trade flows satisfying final consumption from those satisfying intermediate consumption, but treats them together, its usefulness for evaluating the emissions resulting from consumption is limited. It allows the calculation of the emissions generated in a given region in order to produce goods and services destined for export. This is not, however, the total emissions embodied in exported goods and services, because imported intermediate goods and services are usually used during the production, which cause emissions elsewhere. Since this method does not take into account emissions associated with the production of imports, its results cannot be equated with the carbon footprint.

The EEBT methodology is based on the input-output (I-O) analysis developed by Leontief (1941). Since its main assumptions have been described in detail by, among others, Miller and Blair (2009), hereafter only the main formulas are presented.

The economy can be divided into a number not interrelated industry, whose total output is expressed by:

$$
x=A x+y
$$

The vector $\mathrm{x}$ represents the total output in each sector; $A$ is a technical coefficient matrix, whose general elements $a_{i j}$ indicates the demand per unit of production of sector $i$ in sector $j$. Then $A x$ is a vector representing the total intermediate consumption. The elements of the vector $y$ indicate the size of the final demand for the production of each sector. All scales used in the calculations are expressed in terms of value. In order to calculate $x$, the following transformations have to be performed:

$$
\begin{aligned}
& x-A x=y \\
& (I-A) x=y \\
& x=(I-A)^{-1} y
\end{aligned}
$$




\author{
(online) = ISSN $2285-3642$ \\ ISSN-L = 2285 - 3642 \\ Journal of Economic Development, Environment and People \\ Volume 2, Issue 4, 2013 \\ URL: $\underline{\text { http://jedep.spiruharet.ro }}$ \\ e-mail: office jedep@spiruharet.ro
}

In the sequence of Eq. (2), I is the identity matrix, i.e., the matrix with ones the main diagonal zeroes everywhere else. The matrix is $(I-A)^{-1}$ "Leontief 's Inverse matrix", and is fundamental for the input-output analysis. The values in this matrix describe the influence of the exogenous change of the final demand on the total production. It allows tracking of mutual interactions between the elements of the production system, including the analysis of flows between the sectors.

Based on Eq. (1), the total production of a country $r$, denote $\mathrm{dx}^{r}$, can be described with the formula:

$$
x^{r}=A^{r r} x^{r}+y^{r r}
$$

where $y r$ is the vector of the final demand on domestic production, $A^{r r}$ is a matrix in which the entry $a^{r r}{ }_{i j}$ is the amount of input from sector $i$ in country $r$ per dollar's worth of output of sector $j$ in $r$. Then, $A^{r r} x^{r}$ expresses the total intermediate demand in country $r$ for domestic production.

The final demand in Eq. (3) can be expressed as

$$
y^{r r}=c^{r r}+g^{r r}+e^{r}
$$

where $c^{r r}$ is the vector of the final consumption of domestic production, $g^{r r}$ is the vector of government expenseson domestic production, and $e^{r}$ is the vector of export. Therefore, the output equation can be rewritten as

$$
x^{r}=A^{r r} x^{r}+c^{r r}+g^{r r}+e^{r}
$$

and according to Eq. (2),

$$
x^{r}=\left(1-A^{r r}\right)^{-1}\left(c^{r r}+g^{r r}+e^{r}\right)
$$

In order to evaluate the total $\mathrm{CO}_{2}$ emissions created during the production processes in country $r$, the total production has to be multiplied by the $\mathrm{CO}_{2}$ emission factor:

$$
f^{r} \mathrm{CO}_{2}=F^{r} \mathrm{CO}_{2} x^{r}=F^{r} \mathrm{CO}_{2}\left(I-A^{r r}\right)-1\left(y^{r r}+g^{r r}+e^{r}\right)
$$

where $f^{\prime} \mathrm{CO}_{2}$ is the total $\mathrm{CO}_{2}$ emission in country $r$, is a row vector whose elements indicate the amount of $\mathrm{CO}_{2}$ emission per dollar of total output of each sector in country $r$.

The assumption of linearity accompanying the input-output approach allows Eq. (7) to be decomposed and permits evaluation of the effect of each component of the final demand individually. However, because the study focuses on identifying the emission effect caused by export, only this aspect is further considered.

Total $\mathrm{CO}_{2}$ emission generated in country $r$ to meet the total external demand, 

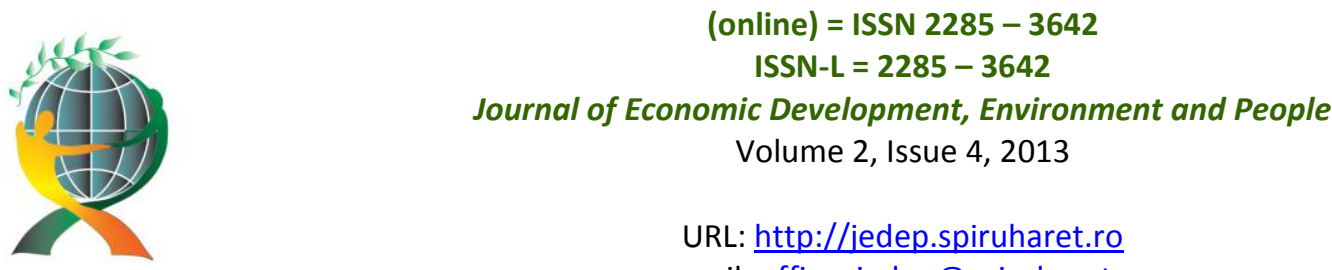

$$
f^{e x} \mathrm{CO}_{2}=F^{r} \mathrm{CO}_{2}\left(I-A^{r r}\right)^{-1} e^{r}
$$

denoted by, can be expressed as

$$
\begin{aligned}
& e^{r}=\Sigma e^{r s} \\
& s
\end{aligned}
$$

Because the export vector $e^{r}$ is the sum of trade flows from country $r$ to country $s$ :

$$
f^{r s} \mathrm{CO}_{2}=F^{r} \mathrm{CO}_{2}\left(I-A^{r r}\right)^{-1} e^{r s}
$$

With a further break-down of Eq. (8) it is possible to capture the emissions embodied in individual trade flows, according to the relation

Where $f^{t s} \mathrm{CO}_{2}$ is the emission embodied in exports from country $r$ to country $s$.

At the same time, Eq. (10) allows the derivation of the emission intensity factor

$$
E_{i}^{r s} \mathrm{CO}_{2}=\frac{f^{r s} \mathrm{CO}_{2}}{e^{r s}}
$$

for exports from country $r$ to country $s$, denoted $E_{i}{ }^{r s} \mathrm{CO}_{2}$, which can be calculated using the formula

Moreover, in the total emission effect of exports from country $r$ to country $s$ calculated according to Eq. (10), the direct and indirect effect is highlighted. The direct effect, denoted by $\mathrm{fd}^{r s} \mathrm{CO}_{2}$ in Eq. (12), concerns $\mathrm{CO}_{2}$ emissions in exporting sectors during the production of goods and services destined for export, and is connected with primary demand.

$$
\mathrm{fd}^{\mathrm{rs}} \mathrm{CO}_{2}=\mathrm{F}^{r} \mathrm{CO}_{2} e^{r s}
$$

The methodology of calculating emissions embodied in bilateral trade also covers emissions generated throughout the whole supply chain of the exporting sectors. These are caused by intermediate demand for domestic goods and services, and constitute an indirect emission effect of exports from country $r$ to country s, denoted in the following equation by:

$$
f_{i}^{r s} \mathrm{CO}_{2}=f^{r s} \mathrm{CO}_{2}-f^{r s} \mathrm{CO}_{2}
$$

The data used in the study are the latest available, and are widely used in contemporary published works (Atkinson, Hamilton et al. 2011; Chen and Chen 2011). 


\author{
(online) $=$ ISSN $2285-3642$ \\ ISSN-L = $2285-3642$ \\ Journal of Economic Development, Environment and People \\ Volume 2, Issue 4, 2013 \\ URL: $\underline{\text { http://jedep.spiruharet.ro }}$ \\ e-mail: office jedep@spiruharet.ro
}

The main source of these data is the Global Trade Analysis Project (GTAP), data base version 7.0.This is a fully documented, publicly available database representing the state of the world economy in 2004.It consists of 113 countries and regions, as well as 57 sectors.

The main file contains the values of flows of goods and services expressed in millions of American dollars (\$m), according to the 2004 exchange rate (Badri Narayanan and Walmsley 2008). All values used in the calculations are in market prices without taxes.

Emission factors were obtained on the basis of estimations performed by Lee (2008).

These data are fully compatible with the GTAP 7.0 database, and were acquired based on fuel emission factors calculated according to the Tier 1methodology of the IPCC (Simon Eggleston, Leonardo Buendia et al. 2006).

\title{
3. Results and discussion
}

The emissions embodied in the total export of Poland were calculated using the relationship shown in Eq.(8), while the individual trade flows between Poland and the countries examined were calculated in accordance with Eq.(10). The aggregated results are shown in Table 1. In 2004, the emissions embodied in the total export from Poland to other countries equaled $78,320.20 \mathrm{GgCO}_{2}$, of which $82 \%$, or $64,346.29 \mathrm{Gg}$ $\mathrm{CO}_{2}$, was exported to Poland's 20 most important trade partners. Chinese researchers (Chen, Chen et al. 2010) using the MRIO methodology (Multi-Regional Input-Output), which includes the emissions embodied in the intermediate use of imports, obtained the total value for Polish exports. The result was over $18 \%$ higher than the value obtained with EEBT.

Among the examined export flows, the greatest amount of emissions were clearly embodied in exports to Germany, coming to a total of $17,944.98 \mathrm{GgCO}_{2}$, which constitutes $23 \%$ of the total emissions embodied in Polish exports at that time. This is associated with the fact that Germany is the biggest recipient of Polish exports.

In the case of imports to Poland, the greatest amount of emissions was embodied in the trade with Russia, equaling $13,930.50 \mathrm{GgCO}_{2}$. This is a consequence of the structure of Polish imports from Russia, which mainly consists of natural resources which involve very high emission levels in Russia during their extraction and transportation.

The second most carbon-intensive source of Polish imports is China, which accounts for 7,654.78 $\mathrm{GgCO}_{2}$. In this case, it is difficult to distinguish groups of goods which might have a significant influence on this result. Probably the low energy efficiency standards combined with the high emission intensity of the energy sector in China have crucial significance here. However, examining the co-responsibility for $\mathrm{CO}_{2}$ emissions created as a result of bilateral trade relations, the most burdened of Poland's trade relations are those with Germany, Russia, the Czech Republic, and China. 


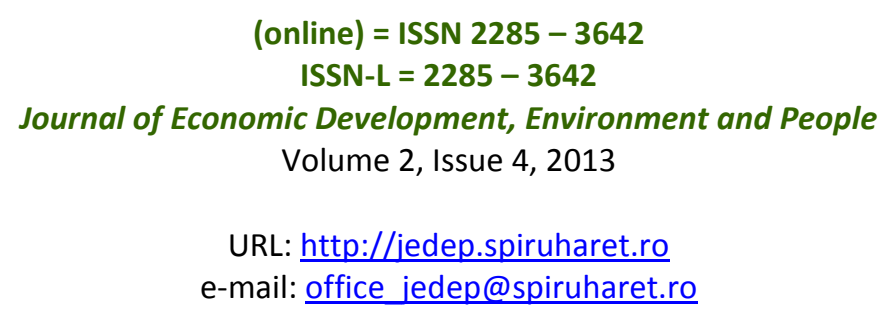

Table $1 \mathrm{CO}_{2}$ emissions embodied in trade between Poland and selected countries in the light of trade volumes

\begin{tabular}{|c|c|c|c|c|c|c|c|}
\hline Country & $\begin{array}{l}\mathrm{CO}_{2} \text { emissions in } \\
\text { exports from Poland }\end{array}$ & $\begin{array}{l}\mathrm{CO}_{2} \text { emissions in } \\
\text { imports to Poland }\end{array}$ & $\begin{array}{c}\text { Total } \mathrm{CO}_{2} \\
\text { emissions in } \\
\text { bilateral trade }\end{array}$ & $\begin{array}{c}\text { Trade } \\
\text { balance } \\
\text { of Poland }\end{array}$ & $\begin{array}{l}\text { Volume of } \\
\text { exports } \\
\text { from Poland }\end{array}$ & $\begin{array}{c}\text { Volume of } \\
\text { imports to } \\
\text { Poland }\end{array}$ & Trade turnover \\
\hline DEU & 17944.98 & 5111.58 & 23056.56 & -3773.22 & 18577.90 & 22351.12 & 40929.02 \\
\hline ITA & 3827.99 & 1998.14 & 5826.13 & -2224.61 & 4658.48 & 6883.09 & 11541.57 \\
\hline FRA & 4235.02 & 1161.99 & 5397.01 & -1234.74 & 4695.10 & 5929.84 & 10624.93 \\
\hline RUS & 2881.29 & 13930.50 & 16811.79 & -3643.90 & 2750.22 & 6394.12 & 9144.34 \\
\hline GBR & 3782.90 & 1382.15 & 5165.05 & 494.56 & 4072.62 & 3578.06 & 7650.68 \\
\hline USA & 3198.31 & 2153.65 & 5351.96 & -285.74 & 3010.10 & 3295.84 & 6305.94 \\
\hline CZE & 6203.39 & 2346.92 & 8550.31 & -172.06 & 3023.96 & 3196.01 & 6219.97 \\
\hline BEL & 2273.58 & 395.41 & 2668.99 & -162.11 & 2633.04 & 2795.14 & 5428.18 \\
\hline SWE & 4149.53 & 259.45 & 4408.98 & 264.43 & 2671.58 & 2407.15 & 5078.73 \\
\hline ESP & 1681.01 & 1004.83 & 2685.84 & -714.67 & 1999.93 & 2714.60 & 4714.53 \\
\hline NLD & 1937.98 & 814.78 & 2752.76 & -459.59 & 1940.08 & 2399.67 & 4339.75 \\
\hline AUT & 2561.17 & 313.51 & 2874.68 & -331.23 & 1582.14 & 1913.38 & 3495.52 \\
\hline HUN & 1652.24 & 440.74 & 2092.97 & 126.56 & 1735.09 & 1608.52 & 3343.61 \\
\hline $\mathrm{CHN}$ & 781.09 & 7654.78 & 8435.87 & -1741.29 & 637.44 & 2378.73 & 3016.17 \\
\hline DNK & 1235.69 & 219.21 & 1454.90 & -108.93 & 1338.85 & 1447.78 & 2786.63 \\
\hline NOR & 1283.36 & 256.08 & 1539.45 & 81.69 & 1339.41 & 1257.71 & 2597.12 \\
\hline JPN & 871.09 & 698.23 & 1569.32 & -921.88 & 821.42 & 1743.30 & 2564.73 \\
\hline UKR & 1551.96 & 2730.56 & 4282.51 & 756.02 & 1653.75 & 897.73 & 2551.48 \\
\hline SVK & 1468.30 & 810.00 & 2278.30 & -254.94 & 1049.49 & 1304.43 & 2353.91 \\
\hline TUR & 825.41 & 634.72 & 1460.13 & -149.00 & 948.33 & 1097.32 & 2045.65 \\
\hline Total & 64346.29 & 44317.22 & 108663.51 & -14454.64 & 61138.91 & 75593.56 & 136732.47 \\
\hline
\end{tabular}




\author{
(online) = ISSN $2285-3642$ \\ ISSN-L = 2285 - 3642 \\ Journal of Economic Development, Environment and People \\ Volume 2, Issue 4, 2013 \\ URL: http://jedep.spiruharet.ro \\ e-mail: office jedep@spiruharet.ro
}

Among the 20 countries examined, the balance of $\mathrm{CO}_{2}$ emissions embodied in Polish foreign trade (Fig.1.) was negative only for Russia, China, and Ukraine. This means that, as a result of the bilateral trade exchange with Poland, these countries release more $\mathrm{CO}_{2}$ than Poland. Ukraine emitted more, despite its negative trade balance with Poland.

In other 17 cases, Poland was a net exporter of carbon emissions. It can be seen that the transfer of net emission to Poland comes from an eastern direction, from countries of lower environmental protection standards, whereas Poland's net carbon emissions were transmitted to wealthier western countries with higher environmental standards than Poland. Altogether, $\mathrm{CO}_{2}$ emissions embodied in Polish exports to the countries examined here were $45 \%$ higher than those calculated in imports, despite the fact that the value of Polish imports exceeded the value of exports by $23 \%$. This was the result of much higher intensity of emissions of Polish exports, in comparison with the intensity of emissions of imports.

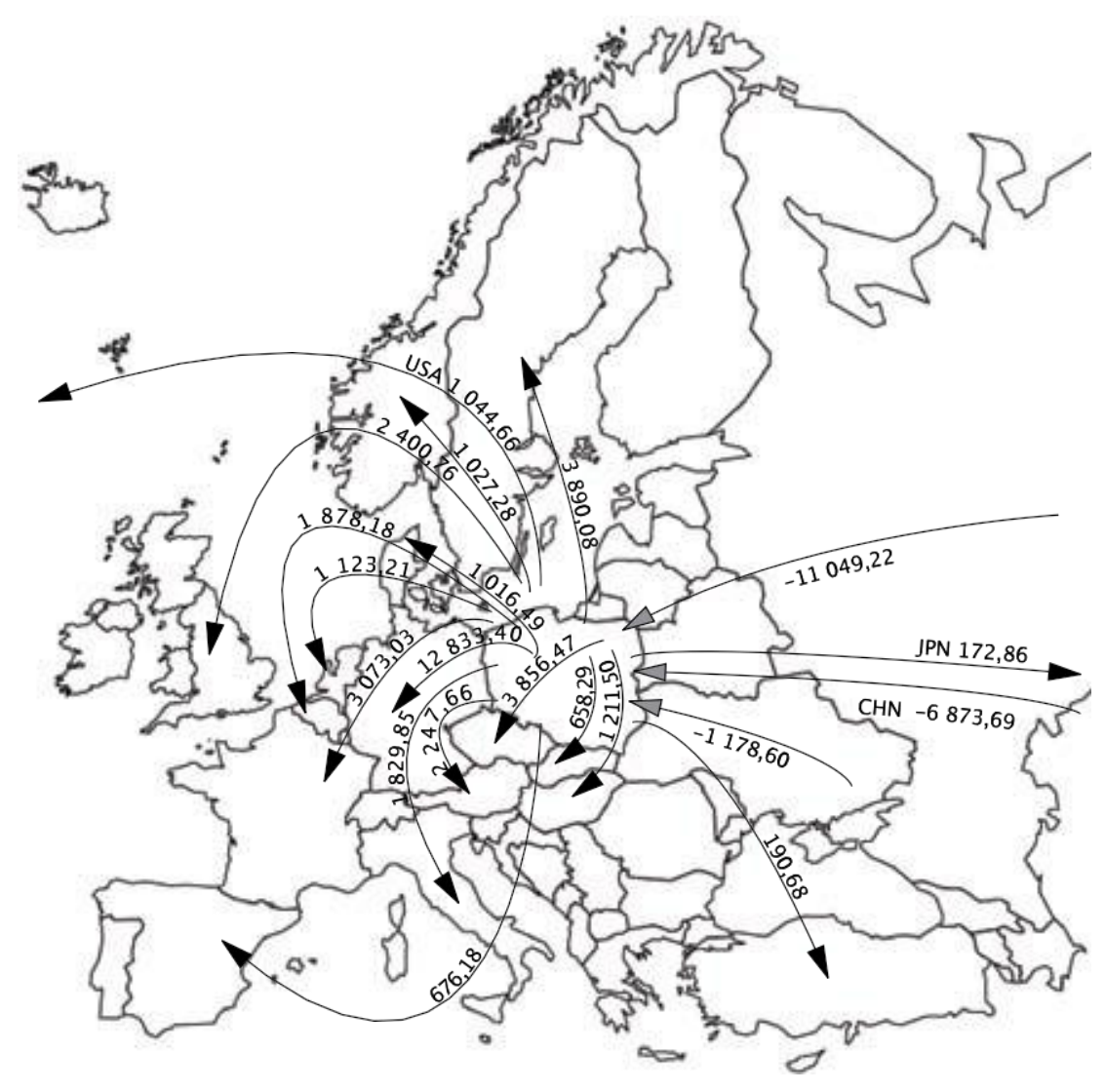

Fig. 1: Net flows of $\mathrm{CO}_{2}$ embodied in bilateral trade between Poland and selected countries in 2004 in 


\author{
(online) $=$ ISSN $2285-3642$ \\ ISSN-L = $2285-3642$ \\ Journal of Economic Development, Environment and People \\ Volume 2, Issue 4, 2013 \\ URL: http://jedep.spiruharet.ro \\ e-mail: office jedep@spiruharet.ro
}

The emission factor of Polish exports ranged from 0.82 to $2.05 \mathrm{Gg} \mathrm{CO}_{2} / \$ \mathrm{~m}$ (Fig. 2). This results from the diversified structure of Polish exports to individual countries. Exports to Italy had the lowest emission intensity, which is linked to the relatively large share of low carbon production in Polish exports to this country. Exports to the Czech Republic were the most emission-intensive, this being caused by the significant amount of electricity and other energy-intensive products involved in the exported goods and services. From among the 20 examined countries, only the emission intensities of imports from China, Russia, and Ukraine were higher than emission intensity factors of export to those countries. Low environmental standards and the crucial role of coal in energy-mixing those countries, as well as the significant quantity of energy-intensive products imported to Poland, probably have main impact on these factors.

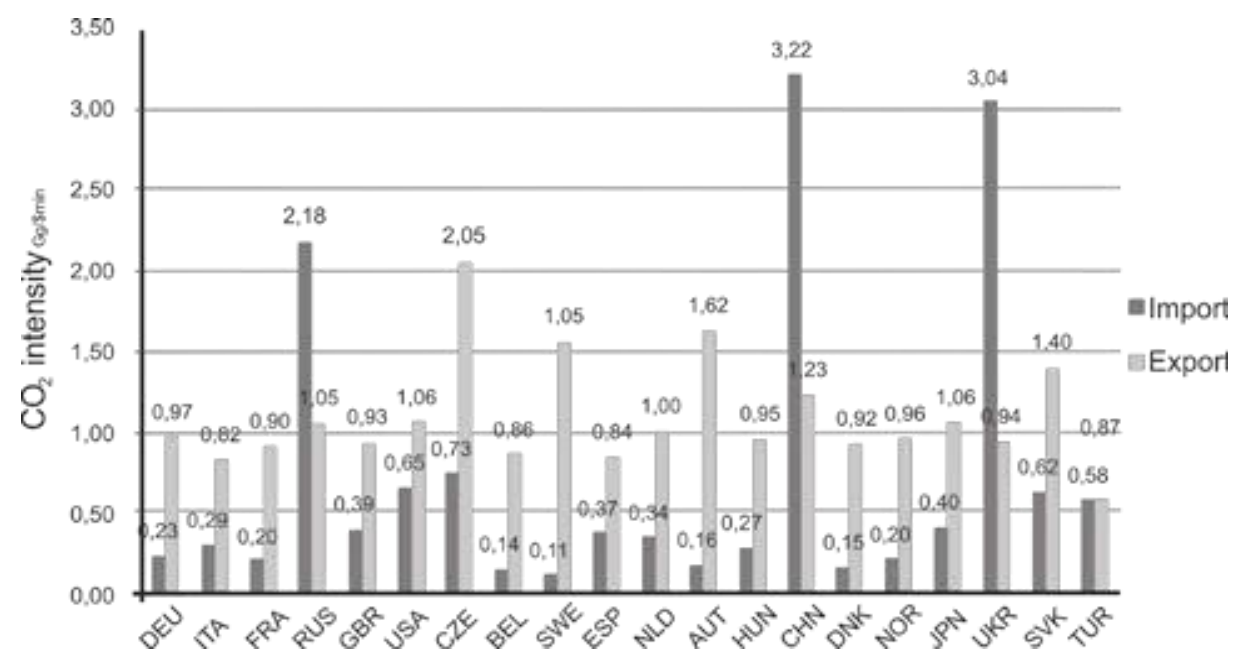

Fig. 2: $\mathrm{CO}_{2}$ emission intensity factors of foreign trade flows of Poland in $\mathrm{Gg} / \$ \mathrm{~min} 2004$

The obtained emission intensity of imports from China of $3.22 \mathrm{Gg} \mathrm{CO}_{2} / \$ \mathrm{~m}$ is significantly different from the result obtained by Liu at al., which considers export from China to Japan in 2000 (Liu, Ishikawa et al. 2010). According to those authors, this factor in 1990 amounted to3.84 $\mathrm{Gg} \mathrm{CO}_{2} / \$ \mathrm{~m}$, and then it decreased, so that in the years 1995 and 2000 it amounted to 1.85 and $0.98 \mathrm{Gg} \mathrm{CO}_{2} / \$ \mathrm{~m}$, respectively. Unfortunately this decrease was not explained, so it is difficult to point out the potential causes of these differences. Divergences are even more puzzling, as the emissions intensity of Japanese exports to China in the years 1995-2000 (quoted in that publication and obtained by the same method) fluctuated in the range of 0.39$0.47 \mathrm{Gg} \mathrm{CO}_{2} / \$ \mathrm{~m}$, and can be compared with the results acquired for flows from Japan to Poland of $0.40 \mathrm{Gg}$ $\mathrm{CO}_{2} / \$ \mathrm{~m}$.

In the next paragraph, based on Eqs. (12) and (13), the emissions embodied in the international trade were divided into indirect and direct emissions (Table 3 ). These results show that indirect $\mathrm{CO}_{2}$ emissions 


\author{
(online) $=$ ISSN $2285-3642$ \\ ISSN-L = 2285 - 3642 \\ Journal of Economic Development, Environment and People \\ Volume 2, Issue 4, 2013 \\ URL: http://jedep.spiruharet.ro \\ e-mail: office jedep@spiruharet.ro
}

induced by Polish exports are almost three times higher than the direct emissions. This means that companies exporting their products from Poland have a much lower influence on emissions embodied in export than their national suppliers. Only exports to the Czech Republic and to Sweden cause a higher direct effect than indirect effect. For other export flows, the relation of the evoked direct emissions to the indirect emissions fluctuated from 1.26 for Austria to 5.93 for Turkey. In case of flows in opposite directions, the direct effect was in every case higher than the indirect one, and its power was almost as much as 10 times higher for imports coming from the United Kingdom. Both in Poland and in its biggest trade partners, the results indicate indirect emissions to be the key emissions source.

Table 2 Direct and indirect $\mathrm{CO}_{2}$ emissions embodied in bilateral trade of Poland in 2004 in $\mathrm{Gg}$

\begin{tabular}{|c|c|c|c|c|c|c|}
\hline \multirow[b]{2}{*}{ Country } & \multicolumn{3}{|c|}{ Export } & \multicolumn{3}{|c|}{ Import } \\
\hline & $\begin{array}{c}\text { Direct } \\
\text { emissions }\end{array}$ & $\begin{array}{l}\text { Indirect } \\
\text { emissions }\end{array}$ & $\begin{array}{c}\text { Ratio of } \\
\text { indirect to } \\
\text { direct } \\
\text { emissions }\end{array}$ & $\begin{array}{c}\text { Direct } \\
\text { emissions }\end{array}$ & $\begin{array}{l}\text { Indirect } \\
\text { emissions }\end{array}$ & $\begin{array}{c}\text { Ratio of } \\
\text { indirect to } \\
\text { direct } \\
\text { emissions }\end{array}$ \\
\hline DEU & 3542.45 & 14402.54 & 4.07 & 917.80 & 1429.12 & 1.56 \\
\hline ITA & 689.83 & 3138.16 & 4.55 & 192.19 & 203.21 & 1.06 \\
\hline FRA & 710.99 & 3524.03 & 4.96 & 1004.27 & 4107.31 & 4.09 \\
\hline RUS & 634.33 & 2246.96 & 3.54 & 130.58 & 182.93 & 1.40 \\
\hline GBR & 816.53 & 2966.37 & 3.63 & 706.32 & 6948.47 & 9.84 \\
\hline USA & 1007.50 & 2190.81 & 2.17 & 62.06 & 157.15 & 2.53 \\
\hline CZE & 3140.02 & 3063.37 & 0.98 & 302.14 & 702.69 & 2.33 \\
\hline BEL & 382.18 & 1891.40 & 4.95 & 396.32 & 765.67 & 1.93 \\
\hline SWE & 2091.61 & 2057.92 & 0.98 & 301.37 & 1080.77 & 3.59 \\
\hline ESP & 298.98 & 1382.03 & 4.62 & 115.56 & 325.18 & 2.81 \\
\hline NLD & 538.05 & 1399.93 & 2.60 & 395.89 & 1602.25 & 4.05 \\
\hline AUT & 1133.76 & 1427.41 & 1.26 & 97.03 & 601.19 & 6.20 \\
\hline HUN & 264.13 & 1388.11 & 5.26 & 272.16 & 542.62 & 1.99 \\
\hline $\mathrm{CHN}$ & 224.43 & 556.66 & 2.48 & 115.18 & 140.90 & 1.22 \\
\hline DNK & 224.56 & 1011.13 & 4.50 & 3041.67 & 10888.83 & 3.58 \\
\hline NOR & 231.81 & 1051.55 & 4.54 & 379.74 & 430.26 & 1.13 \\
\hline JPN & 273.99 & 597.10 & 2.18 & 95.14 & 164.30 & 1.73 \\
\hline UKR & 288.92 & 1263.03 & 4.37 & 202.88 & 431.84 & 2.13 \\
\hline SVK & 440.04 & 1028.25 & 2.34 & 888.35 & 1842.21 & 2.07 \\
\hline TUR & 119.06 & 706.34 & 5.93 & 697.34 & 1456.31 & 2.09 \\
\hline Total & 17053.17 & 47293.11 & 2.77 & 917.80 & 1429.12 & 1.56 \\
\hline
\end{tabular}




\author{
(online) = ISSN $2285-3642$ \\ ISSN-L = 2285-3642 \\ Journal of Economic Development, Environment and People \\ Volume 2, Issue 4, 2013 \\ URL: $\underline{\text { http://jedep.spiruharet.ro }}$ \\ e-mail: office jedep@spiruharet.ro
}

\title{
4. Conclusions
}

Poland exports significantly more emissions than it imports. However, this does not provide us with evidence that trade contributes to larger emissions in Poland than would be the case were there no trade exchange. The negative trade balance of Poland, together with the low emission intensity of imports, suggest that imports may contribute to the significant reduction of emissions, in comparison to the situation where imported goods are produced in Poland. Even so, taking into consideration the structure of Polish exports, which consist of many products from energy-intensive industries, it is possible that emissions created as a result of export exceed the potential benefits of import.

This study has indicated that the largest amount of emissions was created as a result of Poland's trade with EU Member States. These emissions remain under the control of EU climate policy, which aim to reduce them. In the case of the EU countries neighboring Poland, which by their trade with Poland contribute to the generation of significant $\mathrm{CO}_{2}$ emissions, bilateral efforts to curb the emission impact should be considered. Implementing these additional measures could be particularly beneficial in sectors not covered by the EU Emission Trading Scheme. This is because emissions of these sectors are under the influence of domestic policies.

Regarding the phenomenon of "carbon leakage" - understood rather in its "weak" sense in contrast to its "strong" definition (Peters and Hertwich 2008)-we can recognize flows of net embodied emissions which come to Poland from Russia, China, and Ukraine.

This is not only because of the majority share in emissions embodied in the bilateral trade of those countries, but also because of the low environmental standards reflected in the emission intensity of the imports. In order to avoid the development of this leakage, there is a need to further monitor these flows in terms of emission embodied. This is crucial in the context of implementing the ambitious EU climate policy. Despite the provisions in new EU legislation providing special protection to "sectors exposed to the significant risk of carbon leakage", the risk of its escalation is high (2003/87/EC 2009; Clò 2010).

From the analysis presented here, it appears that, for the majority of emissions embodied in trade, indirect emissions were the main source. This demonstrates that, in order to effectively limit the influence of trade exchange on $\mathrm{CO}_{2}$ emission in trading countries, policies should concentrate on comprehensive economy-wide solutions. The improvement of emission parameters in individual sectors, even if their role in export is significant, will probably bring poor results.

Some of the conclusions presented above require further examination, in order to obtain empirical support. Certainly the sect oral analysis of the examined carbon flows would be helpful. The issue of "carbon leakage", too, requires detailed studies. Moreover, carrying out a simulation to assess emissions in Poland under the closed economy assumption would have a crucial cognitive value. 


\author{
(online) = ISSN $2285-3642$ \\ ISSN-L = 2285 - 3642 \\ Journal of Economic Development, Environment and People \\ Volume 2, Issue 4, 2013 \\ URL: http://jedep.spiruharet.ro \\ e-mail: office jedep@spiruharet.ro
}

\title{
5. References
}

[1] 2003/87/EC D. (2009). Directive 2009/29/EC 1. of the European Parliament and of the Council of 23 April 2009 amending Directive 2003/87/EC so as to improve and extend the greenhouse gas emission allowance trading scheme of the Community.

[2] Atkinson G., Hamilton K., Ruta G. and Van Der Mensbrugghe D. (2011). Trade in [']virtual carbon': Empirical results and implications for policy. Global Environmental Change, 21(2), 563-574.

[3] Badri Narayanan and Walmsley T., Eds. (2008). Global Trade, Assistance, and Production: The GTAP 7 Data Base, Center for Global Trade Analysis, Purdue University.

[4] Bernard A. and Vielle M. (2009). Assessment of European Union transition scenarios with a special focus on the issue of carbon leakage. Energy Economics, 31 (Supplement 2), S274-S284.

[5] Chen Z. M., Chen G. Q. and Chen B. (2010). Embodied Carbon Dioxide Emissions of the World Economy: A Systems Input-Output Simulation for 2004. Procedia Environmental Sciences, 2, 1827-1840.

[6] Chen Z. M. and Chen G. Q. (2011). Embodied carbon dioxide emission at supranational scale: A coalition analysis for G7, BRIC, and the rest of the world. Energy Policy, 39(5), 2899-2909.

[7] Clò S. (2010). Grandfathering, auctioning and Carbon Leakage: Assessing the inconsistencies of the new ETS Directive. Energy Policy, 38(5), 2420-2430.

[8] Dissou Y. and Eyland T. (2011). Carbon control policies, competitiveness, and border tax adjustments. Energy Economics, 33(3), 556-564.

[9] Dong Y., Ishikawa M., Liu X. and Wang C. (2010). An analysis of the driving forces of $\mathrm{CO}_{2}$ emissions embodied in Japan-China trade. Energy Policy, 38(11), 6784-6792.

[10] Gavrilova O., Jonas M., Erb K. and Haberl H. (2010). International trade and Austria's livestock system: Direct and hidden carbon emission flows associated with production and consumption of products. Ecological Economics, 69(4), 920-929.

[11] Guo J., Zou L.-L. and Wei Y.-M. (2010). Impact of inter-sectoral trade on national and global $\mathrm{CO}_{2}$ emissions: An empirical analysis of China and US. Energy Policy, 38(3), 1389-1397.

[12] Helm D., Smale R. and Phillips J. (2007) Too good to be true: the UK's climate change

[13] record. http://www.dieterhelm.co.uk/publications/carbon record 2007.pdf (10 June 2011)

[14] Kuik O. and Hofkes M. (2010). Border adjustment for European emissions trading: Competitiveness and carbon leakage. Energy Policy, 38(4), 1741-1748.

[15] Lee H.-L. (2008). The combustion-based $\mathrm{CO}_{2}$ emissions data for GTAP Version 7 Data Base, Center for Global for Global Trade Analysis, Purdue Universty: West Lafayette.

[16] Lenzen M. (1998). Primary energy and greenhouse gases embodied in Australian final consumption: an inputoutput analysis. Energy Policy, 26(6), 495-506.

[17] Leontief W. W. (1941). The structure of American economy, 1919-1929 : an empirical application of equilibrium analysis / by Wasaily W. Leontief. Harvard University Press, Cambridge, Mass. :.

[18] Lin B. and Sun C. (2010). Evaluating carbon dioxide emissions in international trade of China. Energy Policy, 38(1), 613-621.

[19] Liu X., Ishikawa M., Wang C., Dong Y. and Liu W. (2010). Analyses of $\mathrm{CO}_{2}$ emissions embodied in Japan-China trade. Energy Policy, 38(3), 1510-1518. 


\author{
(online) = ISSN $2285-3642$ \\ ISSN-L = 2285 - 3642 \\ Journal of Economic Development, Environment and People \\ Volume 2, Issue 4, 2013 \\ URL: http://jedep.spiruharet.ro \\ e-mail: office jedep@spiruharet.ro
}

[20] Metz B., Davidson O. R., Bosch P. R., Dave R. and Meyer L. A. (2007). Contribution of Working Group III to the Fourth Assessment Report of the Intergovernmental Panel on Climate Change. Cambridge, New York, Cambridge University Press.

[21] Miller R. and Blair P. (2009). Input-Output Analysis: Foundations and Extensions. Cambridge University Press, New York.

[22] Munoz P. and Steininger K. W. (2010). Austria's $\mathrm{CO}_{2}$ responsibility and the carbon content of its international trade. Ecological Economics, 69(10), 2003-2019.

[23] Neuhof R. I. a. K. (2007). Border tax adjustment: a feasible way to support stringent emissions trading. European Journal of Law and Economics, 24, 137-164.

[24] Peters G. (2008). From production-based to consumption-based national emission inventories. Ecological Economics, 65(1), 13-23.

[25] Peters G. P. and Hertwich E. G. (2008). $\mathrm{CO}_{2}$ Embodied in International Trade with Implications for Global Climate Policy. Environmental Science \& Technology, 42(5), 1401-1407.

[26] Rhee H.-C. and Chung H.-S. (2006). Change in $\mathrm{CO}_{2}$ emission and its transmissions between Korea and Japan using international input-output analysis. Ecological Economics, 58(4), 788-800.

[27] Schaeffer R. and Andre L. d. S. (1996). The embodiment of carbon associated with Brazilian imports and exports. Energy Conversion and Management, 37(6-8), 955-960.

[28] Eggleston S., Buendia L., Miwa K., Ngara T. and Tanabe K. (2006). IPCC 2006, 2006 IPCC Guidelines for National Greenhouse Gas Inventories, Prepared by the National Greenhouse Gas Inventories Program me.

[29] Su B., Huang H. C., Ang B. W. and 29. Zhou P. (2010). Input-output analysis of $\mathrm{CO}_{2}$ emissions embodied in trade: The effects of sector aggregation. Energy Economics, 32(1), 166-175.

[30] Subak S. (1995). Methane embodied in the international trade of commodities: Implications for global emissions. Global Environmental Change, 5(5), 433-446.

[31] United Nations Framework Convention on Climate Change. United Nations (1992). FCCC/INFORMAL/84.

[32] Wiedmann T. (2009). A review of recent multi-region input-output models used for consumption-based emission and resource accounting. Ecological Economics, 69(2), 211-222.

[33] Wyckoff A. W. and Roop J. M. (1994). The embodiment of carbon in imports of manufactured products: Implications for international agreements on greenhouse gas emissions. Energy Policy, 22(3), 187-194.

[34] Zhang Z. (2009). Multilateral trade measures in a post-2012 climate change regime? What can be taken from the Montreal Protocol and the WTO? Energy Policy, 37(12), 5105-5112. 